\title{
MINERAL RESOURCE POTENTIAL OF THE CYPRESS ROADLESS AREA, SOUTHERN SIERRA NEVADA, CALIFORNIA
}

\section{SUMMARY REPORT}

\author{
By
}

\author{
George L. Kennedy, Maurice A. Chaffee, James F. Seitz, \\ and Joy L. Harner \\ U.S. Geological Survey
}

and

Donald O. Capstick

U.S. Bureau of Mines

\section{STUDIES RELATED TO WLDERNESS}

Under the provisions of the Wilderness Act (Public Law 88-577, September 3, 1964) and related acts, the U.S. Geological Survey and the U.S. Bureau of Mines have been conducting mineral surveys of wilderness and primitive areas. Areas officially designated as "wilderness," "wild," or "canoe" when the act was passed were incorporated into the National Wilderness Preservation System, and some of them are presently being studied. The act provided that areas under consideration for wilderness designation should be studied for suitability for incorporation into the Wilderness System. The mineral surveys constitute one aspect of the suitability studies. The act directs that the results of such surveys are to be made available to the public and be submitted to the President and the Congress. This report discusses the results of a mineral survey of the Cypress Roadless Area (A5213), Sequoia National Forest, Kern County, California. The area was classified as a further planning area during the Second Roadless Area Review and Evaluation (RARE II) by the U.S. Forest Service, January 1979.

\section{SUMMARY}

A mineral resource appraisal of Cypress Roadless Area, Kern County, California was conducted by the U.S. Geological Survey and the U.S. Bureau of Mines in 1980-1982. Studies included field checking of a previously published geologic map and a reconnaissance geochemical survey by the Geological Survey and a search of mining records and examination of mines, prospects, and mineralized areas by the Bureau of Mines.

These studies indicate that Cypress Roadless Area has: (1) low to moderate potential for possible gold and associated silver resources; and (2) low potential for possible tungsten resources in tactite. There are no indications for the occurrence of coal, oil, gas, or geothermal energy in the roadless area.

\section{INTRODUCTION}

Cypress Roadless Area is small and comprises approximately $3 \mathrm{sq}$ mi $(1,949$ acres) of Sequoia National Forest, Kern County, California. The area is at the southern end of the Sierra Nevada, approximately 30 mi east-northeast of Bakersfield, and $2.5 \mathrm{mi}$ and $3.5 \mathrm{mi}$ south-southeast of the communities of Bodfish and Lake Isabella, respectively (fig. 1). Cypress Roadless Area is bounded on the north by the Sequoia National Forest boundary, on the west and south by Piute Mountain Road (shown as Saddle Spring Road on map sheet), and on the east by Bodfish Creek and patented land of the Glen Olive mine. Access to the roadless area is from Piute Mountain Road and by unimproved dirt roads in Myers and Bodfish Canyons.

Major drainages in the area flow northwestward and are controlled by the regional trend of the metamorphic roof pendants. The western two-thirds of the roadless area is drained by Myers Canyon, and the eastern one-third by Bodfish Creek and its tributaries. The terrain is rugged and steep; elevations range from about 3,900 ft in Myers Canyon at the northern edge of the roadless area to $6,437 \mathrm{ft}$ on the southern ridge crest along Piute Mountain Road.

Vegetation in the roadless area consists of manzanita and sage at lower elevations, deciduous vegetation in damp areas near springs and seasonally flowing streams, and conifers at higher elevations and in cooler north-facing areas. The largest of only nine known groves of Piute cypress, Cupressus nevadensis Abrams, occurs in Cypress Roadless Area and contiguous areas to the north and west.

\section{GEOLOGY}

The geology of Cypress Roadless Area is typical of the southern Sierra Nevada. Intensely deformed Paleozoic(?) to pre-Middle Jurassic metamorphic rocks of sedimentary and volcanic origin occur as roof pendants scattered throughout an intrusive country rock of predominantly Upper Cretaceous granitic rocks of the Sierra Nevada batholith. Scattered gabbroic intrusions of probable Triassic or Jurassic age are also present in the region.

Published geologic studies of the region are few and none of the studies has dealt specifically with the roadless area. Several early studies dealt with mineral resources and production from local mines (see references in Brown (1915 1916), Tucker and Sampson (1940), and Troxel and Morton (1962)), and other studies dealt with possible dam sites on the Kern River in the Isabella Lake area. Miller (1931) presented a geologic section of the southern Sierra Nevada north of the Kern River and named several units in the area, including the Kernville Series and the Isabella Granodiorite. Miller and Webb (1940) described the geology of the old (1908) 30-minute Kernville quadrangle, which includes the roadless area, and named additional units, including the Summit Gabbro. The geology of the southern Sierra Nevada has been summarized in the geologic maps by Troxel and Morton (1962, pl. 2) and Smith (1965). The latter map included previously unpublished mapping that extended the known distribution of metamorphic rocks of the Kernville Series into an area on the east side of Bodfish Canyon, northeast of the roadless area.

The oldest rocks in the region are metamorphic rocks of the Kernville Series of Miller (1931). The Kernville Series includes a variety of metasedimentary and metavolcanic 
rocks that occur in roof pendants in the southern end of the Sierra Nevada batholith. In Cypress Roadless Area the Kernville is dominantly quartzite with lesser amounts of schist. Strikes are generally parallel or subparallel to the regional trend of local roof pendents; dips are steep to vertical. Contacts with the Summit Gabbro of Miller and Webb (1940) and Isabella Granodiorite of Miller (1931) vary from sharp to gradational zones of mixed intrusive and metasedimentary rocks. The age of the Kernville Series is Paleozoic(?) to pre-Middle Jurassic, but the lack of fossils in the area prevents a more precise age determination. Saleeby and others $(1978$, p. 322$)$ reported Late Triassic to Early Jurassic mollusks from another roof pendant approximately 8 mi east-northeast of the roadless area.

Most of the plutonic rocks of the Sierra Nevada batholith are granitic, but a few small gabbroic plutons of probable Triassic or Jurassic age occur throughout the region. A small area of the Summit Gabbro of Miller and Webb (1940) is exposed in the northwestern part of the roadless area.

The Upper Cretaceous Isabella Granodiorite of Miller (1931) is the most extensive intrusive rock in the roadless area, but locally may vary in composition from granodiorite through tonalite to hornblende diorite. Typical exposures of granodiorite are deeply weathered and covered with a veneer of grus. A shallowly eastward-dipping system of quartzofeldspathic to milky-quartz dikes and veins occurs in the granodiorite in a north-trending fault system in Myers Canyon.

Metallic minerals in and near the roadless area occur in two geologic environments (Capstick, 1983, p. 7). Hydrothermal gold deposits containing silver and minor antimony are the most pervasive and are associated with late stage differentiates (quartzo-feldspathic dikes and veins) injected into fault fractures (Alvarez, 1962, p. 36). Later stages of mineralization were accompanied by faulting and brecciation of the host rocks. Gold was concentrated further by postfaulting metasomatism. Contact metasomatic mineral occurrences in the region consist of tungsten minerals (scheelite) associated with tactite. Protolithic calcareous rocks necessary for tactite formation were probably scarce in the area, and little tactite was formed.

\section{GEOCHEMISTRY}

The geochemical survey of Cypress Roadless Area is based on chemical analyses of 33 rock samples, 34 minus-60mesh stream-sediment samples, and 33 nonmagnetic heavymineral-concentrate samples collected in 1980 and 1981 (Sutley and others, 1983). Some of these samples were collected from outside of the roadless area in order to increase the size of the analytical data base. All samples were analyzed for 31 elements $(\mathrm{Ag}, \mathrm{As}, \mathrm{Au}, \mathrm{B}, \mathrm{Ba}, \mathrm{Be}, \mathrm{Bi}, \mathrm{Ca}$, $\mathrm{Cd}, \mathrm{Co}, \mathrm{Cr}, \mathrm{Cu}, \mathrm{Fe}, \mathrm{La}, \mathrm{Mg}, \mathrm{Mn}$, Mo, Nb, Ni, Pb, Sb, Sc, Sn, $\mathrm{Sr}, \mathrm{Th}, \mathrm{Ti}, \mathrm{V}, \mathrm{W}, \mathrm{Y}, \mathrm{Zn}$, and $\mathrm{Zr}$ ) using a six-step semiquantitative emission spectrographic method. In addition, rock and stream-sediment samples were analyzed for gold and zinc by atomic-absorption spectrometry and for uranium by a fluorometric method.

Rock samples collected by the Bureau of Mines were checked for radioactivity and fluorescence, and fire assayed for gold and silver. Samples with visible or suspected minerals were quantitatively analyzed by atomic absorption, colorimetric, or X-ray fluorescence methods. At least one sample from every mine or prospect was analyzed for selected elements by semiquantitative spectrographic methods.

The presence of anomalous concentrations of certain elements in rocks or stream sediments may be indicative of possible mineralization in an area. For rock samples, the presence of arsenic, gold, or silver is of particular interest because of their relationship to the types of mineralization that may occur in the roadless area. In a similar manner, gold, lead, molybdenum, or silver are possible indicators of mineralization when found in anomalous concentrations in stream sediments, and 11 elements ( $\mathrm{Ag}, \mathrm{As}, \mathrm{Au}, \mathrm{B}, \mathrm{Bi}, \mathrm{Cu}$, $\mathrm{Mo}, \mathrm{Pb}, \mathrm{Sb}, \mathrm{Sn}$, and $\mathrm{W}$ ) are possible indicators when found in anomalous concentrations in heavy-mineral concentrates.

\section{Rock samples}

Nine of the 33 rock samples collected by the Geological Survey contained anomalous concentrations of arsenic, gold, or silver. The anomalous samples were collected from both the Isabella Granodiorite and various metasedimentary units of the Kernville Series. The anomalies appear to be related to quartz-vein mineralization in these units, rather than to the primary lithology of the host rocks.

One hundred seventy-eight rock samples were collected at 11 mines and prospects by the Bureau of Mines. Gold $(0.005 \mathrm{oz}$ per ton or greater) was detected in 34 percent of the 123 chip samples collected; 28 percent contained between 0.005 and $0.01 \mathrm{oz}$ gold per ton and 6 percent contained 0.01 to $1.09 \mathrm{oz}$ gold per ton.

\section{Stream-sediment and concentrate samples}

Anomalous concentrations of elements possibly related to mineralization are present in both stream-sediment and nonmagnetic heavy-mineral-concentrate samples from throughout the study area. Anomalies in stream sediments, which are probably related to gold and (or) silver mineralization, are highest in samples collected in upper Bodfish Canyon. These anomalies probably indicate contamination from mining and milling at the Glen Olive mine (fig. 2) and from workings at other prospects, but they also may be indications of additional mineralized areas. Slightly anomalous concentrations of gold and silver are also present in samples collected in Myers Canyon. These anomalies are thought to be related to the system of quartzofeldspathic dikes and veins that is exposed on the east side of Myers Canyon.

Two suites of elements are present in anomalous concentrations in heavy-mineral-concentrate samples. Restricted anomalies for one or more of the elements antimony, arsenic, copper, gold, or silver are present in samples collected from drainages on the west side of Bodfish Canyon and on the east side of Myers Canyon. The most significant of these anomalies may be the result of contamination from mining and milling activity in the Glen Olive mine area. Geologically these anomalies appear to be related to mineralized quartzo-feldspathic dikes and veins that predominantly occur in the Isabella Granodiorite.

Elements that are characteristic of metasomatic contact-type tungsten mineralization ( $\mathrm{B}, \mathrm{Bi}, \mathrm{Mo}, \mathrm{Pb}, \mathrm{Sn}, \mathrm{W}$ ) were found throughout the area in many of the nonmagnetic heavy-mineral-concentrate samples. However, because several of these elements, notably tungsten, also occur in mineralized quartz-vein type deposits in surrounding areas (Troxel and Morton, 1962), the more intense of the anomalies, in drainages near the Glen Olive mine, may be the result of contamination from mining and milling activity there. Similar, although weaker, anomalies for the same elements occur within the roadless area in samples from Myers Canyon and outside the roadless area in samples from the east side of Bodfish Canyon, in the small unnamed canyons directly south of Bodfish, and in an unnamed canyon that drains westward from the vicinity of Bald Eagle Peak. These anomalies may indicate either (1) contact-type mineralization, although limestone is generally rare in the area, or (2) quartz-vein mineralization that may be more widespread thoughout the area. The sources of these minor anomalies have not been identified.

\section{MINES AND MINING DISTRICTS}

Mines and prospects in the vicinity of the roadless area are encompassed by the poorly defined Pioneer mining district, an area also loosely referred to as the northwestern part of the Piute Mountains mining district (Troxel and Morton, 1962, p. 24, 31). Clark (1970, p. 46) assigned the roadless area to the Erskine Creek mining district, although that district is often restricted to a narrow region on either side of Erskine Creek, 2 to $3 \mathrm{mi}$ to the east (Troxel and Morton, 1962, p. 31). The Clear Creek mining district, located 
weat of the roadless area, is centered on lower Clear Creek and is coincident with part of the Kern River uranium area of MacKevett (1960).

Gold

Production from Sierran gold mines is dominantly from quartz and (or) quartzo-feldspathic dikes and veins in granitic host rocks. Lode gold was first mined in the Kern River basin in 1852 and by the middle 1860 's substantial amounts were being produced from four local mining districts, none very far from the roadless area. The total production of gold and associated silver from these districts has been estimated at between four and eight million dollars $(250,000$ to $400,000 \mathrm{oz}$ gold), although no production records are available for the period prior to 1880 (Troxel and Morton, 1962, p. 92; Capstick, 1983).

Lode gold has been produced from several mines along the ridge of Isabella Granodiorite that extends through, and southeast of, the roadless area. At the Glen Olive mine, just outside of the area, free-milling gold was produced from two quartz veins that strike northwest and dip to the northeast (Troxel and Morton, 1962, p. 151). The mine was located about 1888 and yielded an estimated $\$ 500,000$ (about 25,000 oz) in gold by 1914; considerably less has been produced since, although it was operated almost continuously until its closing in 1942. Work was underway on the Glen Olive mill in 1982 in anticipation of renewed production.

Numerous prospect pits and adits are present on the west-facing slope of Myers Canyon and a few appear to have had limited, although mainly unrecorded, production; none is currently being worked, although 15 claims are still actively held (Capstick, 1983). The prospects here are probably all gold workings, as gold was found in most of the properties sampled. The Polar Bear mine (fig. 2), thought to be in the northernmost group of workings, is reported to have had pre1916 production. The Pickwick mine (fig. 2), known to comprise some of the central workings, produced until about 1935. Combined production from these two is estimated to be at least $861 \mathrm{oz}$ of gold (Capstick, 1983). Other workings (table 1) along or near this trend of prospects include the Rocky Hill, Devils Hole North and South, and Opportunity Subsection No. 4 prospects. Limited production is suggested also by the extent of workings at what may be the Fairview mine (fig. 2), near the northeastern corner of the roadless area (Capstick, 1983).

\section{Tungsten}

Tungsten ore was first mined in Kern County in 1905. Production was limited, however, until greater demand and higher prices were spurred by the advent of World War I. Production ceased after the war, but continued intermittently with minor production between 1929 and 1950. When the importation of tungsten from China ended in 1950, additional sources were sought and encouraged by price supports from the U.S. Government. Most of the mines and prospects in Kern County were discovered in the period 1951-1956. Production declined dramatically again in 1957, when price supports were withdrawn (Troxel and Morton, 1962, p. 294295).

Scheelite, a tungsten mineral, has been produced from quartz veins and from tactite deposits in the Kernville Series in roof pendants that are located immediately east and west of the roadless area. The Tripoli prospect, the only tungsten prospect in Cypress Roadless Area, is on the west side of the area at the contact between the Kernville Series and the Summit Gabbro. Workings consist of one hand-dug trench and several bulldozer cuts in a tactite zone. No production has been recorded from the Tripoli prospect and none is suspected (Troxel and Morton, 1962; Capstick, 1983).

\section{Antimony}

Stibnite and, locally, native antimony have been mined from quartzose bodies in shear zones that cut granitic rocks or metamorphosed sedimentary rocks east, west, and south of the roadless area, in the Erskine Creek, Clear Creek, and
Piute Mountains mining districts, respectively (Troxel and Morton, 1962). The only antimony ore produced from the roadless area was a 2-ton deposit associated with a gold occurrence at the Opportunity Subsection No. 4 prospect (fig. $2)$. The ore was valued at $\$ 540$ per ton, but the deposit has been depleted and no further resources remain (Capstick, 1983).

\section{Uranium}

Uranium was first discovered in 1954 in the Kern River uranium area (MacKevett, 1960) near Miracle Hot Springs, 3 mi west-northwest of Cypress Roadless Area (fig. 1). The uranium minerals are secondary and occur in small deposits that are erratically distributed along faults and fracture systems in the Isabella Granodiorite. Total production from several mines in the area was limited to 189 tons of ore (MacKevett, 1960; Troxel and Morton, 1962).

\section{ASSESSMENT OF MINERAL RESOURCE POTENTIAL}

Mineral resource potential of Cypress Roadless Aree has been determined on the basis of several criteria: (1) magnitude and location of geochemical anomalies in rocks, stream sediments, and heavy-mineral concentrates; (2) geologic favorability for the occurrence of mineral deposits; (3) similarity of geologic setting to those of nearby areas with known resources; and (4) history of mining and examination of known mines and prospects (table 1).

Cypress Roadless Area lies in an areally extensive geologic terrain that over the past 100 years has yielded locally small amounts of tungsten, base-metal, and uranium minerals along with substantial amounts of gold and associated silver. However, on the basis of the geologic reconnissance, a geochemical survey of rock and streamsediment samples (Sutley and others, 1983; Chaffee and others, 1984), and examination of mines and prospects (Capstick, 1983), the area has a low to moderate potential for possible deposits of lode gold with associated silver and a low potential for possible tungsten deposits associated with tactite.

\section{Gold}

Lode gold has been produced from the Glen Olive mine and other mines along the ridge of Isabella Granodiorite that extends through, and southeast of, the roadless area (table 1). The gold-bearing quartz veins at the Glen Olive mine may be genetically related to the shallowly eastward-dipping system of quartzo-feldspathic to milky-quartz dikes and veins that crops out in the Isabella Granodiorite below Bodfish Peak on the east side of Myers Canyon. These gold-bearing late differentiates were emplaced in a north-northwest trending fault system that runs through the center of the roadless area. At least 30 adits have been driven in this system within the roadless area; a few have had limited production. One, the Polar Bear mine, is reported to have pre-1916 production. Another, the Pickwick mine, produced until about 1935. Combined production from these two is estimated to be at least $861 \mathrm{oz}$ of gold. Analyses of samples from these workings suggest sporadic distribution of the gold, a characteristic apparently shared by similar prospects and mines in the region.

Within the area that is geologically favorable for the occurrence of gold-bearing guartz veins, four areas are identified that might have mineral resource potential (fig. 2). Of these areas, one has moderate potential and three have low potential for gold resources with accessory silver. On the basis of past production and assay values of collected samples, the area in and around the workings that comprise the Devils Hole mine (including the old Pickwick mine) has moderate potential for possible gold resources. The areas around the northernmost group of workings that comprise the Heavens Delight mine (including the old Polar Bear mine) and Rocky Hill prospect and two groups of workings that comprise the Devils Hole North and Devils Hole South prospects have a low resource potential. Resource potential at the Glen Olive mine, however, is high (Capstick, 1983). 
Anomalous concentrations of gold and silver were recovered from stream-sediment and heavy-mineralconcentrate samples from Myers Canyon in the roadless area and from areas draining Isabella Granodiorite outside the roadless area. However, the extensive bedrock exposures and concomitant lack of gravel accumulations in Myers Canyon due to the steep terrain precludes even a low potential for heavy-metal placer resources in the roadless area.

\section{Tungsten}

Metamorphic rocks of the Kernville Series in roof pendants east and west of the roadless area have yielded small amounts of tungsten ore. Scheelite, a tungsten mineral, occurs in small amounts in association with limited tactite at the Tripoli prospect in the northwestern part of the roadless area. The occurrence is in the contact zone between the Kernville Series and the Summit Gabbro. Samples from this prospect assayed $0.03,0.26$, and 0.5 percent tungsten trioxide $\left(\mathrm{WO}_{3}\right)$, but the occurrence contains no identified resources. No production has been recorded from the Tripoli prospect and none is suspected (Troxel and Morton, 1962, p. 324; Capstick, 1983).

No tactite was observed in the mixed zone of metamorphic and granitic rocks in Myers Canyon, and outcrops of metamorphosed limestone are rare and of limited extent. Stream-sediment and heavy-mineral-concentrate samples from throughout the area contain slightly anomalous concentrations of elements related to tungsten-type mineralization, but none of these anomalies appears to be highly significant. On the basis of this evidence, Cypress Roadless Area has only a low potential for possible tungsten resouces.

\section{Antimony}

Stibnite and, locally, native antimony have been produced from mining districts that are immediately east, west, and south of the roadless area. Two tons of antimony ore were mined in the roadless area in Myers Canyon at the Opportunity Subsection No. 4, a gold prospect. The deposit has been depleted and no further resources remain (Capstick, 1983).

\section{Uranium}

The Isabella Granodiorite locally contains abnormal amounts of uranium in the Kern River uranium area (MacKevett, 1960) about $3 \mathrm{mi}$ west-northwest of the roadless area. No anomalous uranium was detected in the rock or stream-sediment samples that were analyzed for this study, and there is no indication of uranium resources in the roadless area.

\section{Geothermal energy}

Hot springs are locally present in the southern Sierra Nevada, and are usually associated with faults. The closest hot springs are about $3 \mathrm{mi}$ west-northwest of the roadless area at Miracle Hot Springs (fig. 1). The absence of hot spring activity in Cypress Roadless Area suggests that no potential exists here for geothermal energy.

\section{Other commodities}

Marble is present in the Kernville Series in roof pendants both east and west of the roadless area. Because it comprises a very small part of the metamorphic rock in Cypress Roadless Area, marble is not a potential resource.

Stone suitable for various construction purposes is present in the roadless area. However, because transportation is a major factor in the production of this high-bulk, low-unit-value commodity, deposits in the roadless area cannot compete favorably with similar deposits closer to populated areas.

\section{REFERENCES CITED}

Alvarez, Leonardo, 1962, Geology of the Isabella area, Kern County, California: Salt Lake City, University of Utah, M.S. thesis, 51 p.

Brown, G. C., 19151916 , Kern County, in Mines and mineral resources of portions of California, Part IV: California State Mining Bureau, Report of the State Mineralogist, v. 14, p. $471-523$.

Capstick, D. O., 1983, Mineral resources of the Cypress RARE II area (No. A5213), Kern County, California: U.S. Bureau of Mines Mineral Land Assessment MLA $64-83,18 \mathrm{p}$.

Chaffee, M. A., Fey, D. L., Hill, R. H., and Sutley, S. J., 1983, Geochemical maps showing distributions of anomalous element concentrations and of anomalous drainage basins, Cypress Roadless Area, Kern County, California: U.S. Geological Survey Miscellaneous Field Studies Map MF-1532-B, scale 1:24,000 [in press ].

Clark, W. B., 1970, Gold districts of California: California Divison of Mines and Geology Bulletin 193, $186 \mathrm{p}$.

MacKevett, E. M., Jr., 1960, Geology and ore deposits of the Kern River uranium area, California, in Contributions to the geology of uranium: U.S. Geological Survey Bulletin 1087-F, p. 169-222.

Miller, W. J., 1931, Geologic sections across the southern Sierra Nevada of California: University of California Publications, Bulletin of the Department of Geological Sciences, v. 20, no. 9, p. 331-360.

Miller, W. J., and Webb, R. W., 1940, Descriptive geology of the Kernville quadrangle, California: California Journal of Mines and Geology, v. 36, no. 4, p. 343-378.

Saleeby, J. B., Goodwin, S. E., Sharp, W. D., and Busby, C. J., 1978, Early Mesozoic paleotectonic-paleogeographic reconstruction of the southern Sierra Nevada region, in Howell, D. G., and McDougall, K. A., eds., Mesozoic paleogeography of the western United States, Pacific Coast Paleogeography Symposium 2: Los Angeles, Society of Economic Paleontologists and Mineralogists, Pacific Section, p. 311-336.

Smith, A. R., compiler, 1965, Bakersfield sheet, Geologic map of California, Olaf P. Jenkins edition: California Division of Mines and Geology, Geologic Atlas of California, scale 1:250,000.

Sutley, S. J., Chaffee, M. A., Fey, D. L., and Hill R. H., 1983, Chemical analyses and statistical summaries for samples of rock, minus-60-mesh $(0.25-\mathrm{mm})$ stream sediment, and nonmagnetic heavy-mineral concentrate, Cypress Roadless Area, Kern County, California: U.S. Geological Survey Open-File Report 83-643, 19 p.

Troxel, B. W., and Morton, P. K., 1962, Mines and mineral resources of Kern County, California: California Division of Mines and Geology County Report 1, 370 p.

Tucker, W. B., and Sampson, R. J., 1940, Mineral resources of the Kernville quadrangle: California Journal of Mines and Geology, v. 36 , no. 4, p. 322-333. 
Table 1.--Mines and Prospects in and adjacent to the Cypress Roadless Area [Underlined name indicates potential for mineral resources]

\begin{tabular}{|c|c|c|c|c|}
\hline $\begin{array}{l}\text { Map } \\
\text { No. }\end{array}$ & Name & Summary & Workings and Production & $\begin{array}{l}\text { Sample Data and } \\
\text { resource potential estimate }\end{array}$ \\
\hline 1 & Unnamed prospect & $\begin{array}{l}\text { A } 0.9-\mathrm{ft} \text {-thick quartz vein strikes } \mathrm{N} \text {. } \\
17^{\circ} \text { E. and dips } 70^{\circ} \mathrm{NW} \text {. } \\
\text { in argillaceous metasedimentary rocks. }\end{array}$ & $\begin{array}{l}\text { Three caved adits that trend northeasterly } \\
\text { are estimated to have working of about } 30 \text {, } \\
100 \text {, and } 150 \mathrm{ft} \text {. }\end{array}$ & $\begin{array}{l}\text { One sample of vein quartz ylelded no } \\
\text { significant values. }\end{array}$ \\
\hline 2 & $\frac{\text { Heavens }}{\text { (Polar Belight }}$ & $\begin{array}{l}\text { Veins and pods of quartz within } \\
\text { quartzo-feldspathic dikes up to } 6 \mathrm{ft} \\
\text { thick trend northeast and dip } 5 \text { to } 60 \\
\text { degrees, generally to the southeast, in } \\
\text { granodiorite. Free-milling gold was } \\
\text { reported in the dikes. A } 0.5-\text { to } 2.2-\mathrm{ft}- \\
\text { thick quartz vein is exposed for the } \\
\text { length of a } 55-\mathrm{ft} \text { adit, and has yielded } \\
\text { the highest gold values near the } \\
\text { portal. The vein had the highest } \\
\text { average grade of the workings in the } \\
\text { group. Brown's (19is }[1916] \text {, p. 507) } \\
\text { description of the Polar Bear mine } \\
\text { suggests ti may be within this claim group. }\end{array}$ & $\begin{array}{l}\text { Three open adits, } 25,55 \text {, and } 155 \mathrm{ft} \\
\text { long; stx caved adits, the largest } \\
\text { estimated to have } 600 \text { ft of workings; } \\
\text { and one } 12-\mathrm{ft}-\mathrm{d} \text { lameter pit. } \\
\text { Brown (1915 [1916], p. } 507 \text { ) reported pro- } \\
\text { duction of } \$ 8,000 \text { worth (about } 400 \mathrm{oz} \text { ) } \\
\text { of free mil11ng gold. U.S. Bureau of } \\
\text { Mines production records, which may be } \\
\text { Incomplete, Indicate a yield of } 215 \mathrm{oz} \\
\text { gold from } 1898 \text { through } 1911 \text {. }\end{array}$ & $\begin{array}{l}\text { Thirty-one samples: two contained } \\
\text { greater than } 0.10 \text { oz gold per ton and } \\
\text { were from a quartz vein in a dike. The } \\
\text { samples from the vein averaged about } \\
0.15 \text { oz gold and } 0.2 \text { oz silver per ton } \\
\text { with } 0.53 \text { percent arsenic. Estimated } \\
\text { gold-bearing rock in the area sampled } \\
\text { 1s } 1,700 \text { tons averaging } 0.05 \text { oz gold } \\
\text { per ton. Two samples of vein quartz } \\
\text { and quartzo-feldspathic debris from } \\
\text { stockp1les at the } 155-\mathrm{ft} \text { adit and a } \\
\text { caved pit contained } 1.436 \text { oz and } 2.20 \\
\text { oz gold per ton. There } 1 \text { s low } \\
\text { potential for gold resources. }\end{array}$ \\
\hline
\end{tabular}

3 Unnamed prospect ${ }^{1} \quad$ Quartz veins in granodiorite as evidenced by materials found on dumps. Thickness because workings are inaccessible.

4 Rocky Hi11 prospect. A 3.4-ft-thick quartzo-feldspathic dike trends N. $33^{\circ} \mathrm{E}$. and dips $44^{\circ} \mathrm{SE}$. in granodiorite.
Massive quartzite (attitude indeterminate) One (haulage?) adit $450 \mathrm{ft}$ 1ong, and is in fault contact with dark granodiorite; one caved inclined shaft estimated to a 0.5 -ft-thick quartz veln strikes $\mathrm{N}$. $5^{\circ} \mathrm{E}$. be at least $225 \mathrm{ft}$ long if connected and dips $22^{\circ} \mathrm{SE}$. in granodiorite. A dump with caved ratse at end of adit. consisting predominantly of granodiorite, near the caved shaft, contains minor amounts of veln quartz and metasedimentary rocks.

6 Tripoli prospect

A north-trending zone of fault breccia and gouge in a quartzo-feldspathic dike up to $2.9 \mathrm{ft}$ thick; exposed only in one exploration trench. Garnet-epidote tactite up to $3.5 \mathrm{ft}$ wide occurs in a small nearby outcrop.

Two caved shafts estimated to have

One adtt 22. ft long.

One hand-dug trench $100 \mathrm{ft}$ long and $30 \mathrm{ft}$ wide; numerous bulldozer roads and trenches on the property.

\section{Devils $\frac{\text { Hole }}{\text { prospect }}$ North}

\section{Devils $\frac{\text { Hole }}{\text { (Pickwick) }}$ mine}

Locally brecciated quartzo-feldspathic dike up to $4.5 \mathrm{ft}$ thick. Att1tude of dike differs considerably from one place to another, but it generally strikes east
and dips souther $1 \mathrm{y}$ about $10^{\circ}$ to $80^{\circ}$.

Locally brecciated quartzo-feldspathlc dikes up to $3 \mathrm{ft}$ thick. Attitude of dike differs considerably from one place to another, but generally they strike easterl
and dip southerly about $10^{\circ}$ to $80^{\circ}$. Free milling gold was probably mined from quartz-rich zones and veins in the dikes, and from the dikes themselves. The dikes in the various workings seen to be echelon within granodiorite country rock. Consequent $1 y$, continutty was not assumed between individual workings.

Brecciated quartz fragments and pods averaging $2.8 \mathrm{ft}$ wide are in altered granodiorite and brecciated metasediments. Workings are in a $0.25-$ m1-wide contact zone of mixed intrusive
and metasedimentary rock.

10 Devils Hole South prospect

11 Glen Olive mine
A sheared quartzo-feldspathic dike averaging $1.3 \mathrm{ft}$ thick trends northeast

The largest producer in the Pioneer mining district. Free milling gold is found within quartz-rich zones, originally reported to be "quartz veins" (Troxe1 and Morton, 1962, p. 151), In granodiorite country rock. The property is patented less area's southeast boundary.
Seven open adits, the largest with about $560 \mathrm{ft}$ of workings; four caved adits, th largest estimated to have about $400 \mathrm{ft}$ of workings; one shaft, caved at $11 \mathrm{ft}$, and estimated to be $20 \mathrm{ft}$ deep.

Six open adits, the largest with about $570 \mathrm{ft}$ of workings; two caved adits, the largest estimated to have about $800 \mathrm{ft}$ of workings.

Bureau of Mines production records, which may be incomplete, indicate at least 461 o of gold were extracted from the Pickwick workings from 1897 through 1935.

One 125-ft-long adit, one caved adit, two or three probable caved adits; all dunps were destroyed by bulldozer work. Richard Dummar, the last known claimant, related that about 2 tons of antinony ore valued at $\$ 540$ per ton was mined from a small pocket in one were found.

One 150-ft-long adit and one 110-ft-long open cut:

Numerous adits, raises, winzes, drifts, and stoped areas. Mine workings were accessed by and ang and equipment, an assay laboratory, and a mill are monitored by a caretaker. mill was being revamped in 1982 in antictpation of renewed production. About 25,000 oz of gold was produced between about Intermittent production continued until 1942.
One sample of vein quartz yielded no significant values.

Two samples: A chip sample from the quartzo-feldspathic dike contained 0.08 oz gold per ton; a grab sample from a stockpile contained 0.47 oz gold per ton. The prospect has low potential for gold resources.

Seven samples: three samples of vein quartz and massive quatzite within adtt contained traces of gold; a sample of the vein quartz from the shaft dump contained 0.19 oz gold per ton.

Seven samples: one chip sample of dike rock contained $0.028 \mathrm{oz}$ gold per ton; sample of fault gouge and another of breccia in a quartzo-feldspathic dike contained 0.52 and 0.03 percent tungsten trioxide ( $\mathrm{WO}_{3}$, respectively; a sample from a stockpile contained 0.26 percen $W_{3}$. A sample from the garnet-epidote tactite outcrop yielded no significant element values.

Sixty-four samples: six chip samples contained gold. Three had 0.008 oz gold per ton; the others had 0.029 , and 0.042 gold per ton. The prospect has low potential for gold resources.

Forty-eight samples: 42 were from the dikes, 28 of these contained gold; the remainder were from dumps and probable stockpiles. Five of the dike samples contained from 0.23 to 0.69 oz gold per ton. Of the 4 samples from probable stockpiles, 3 contained greater than 0. oz gold per ton, and ranged from 0.24 to 0.28 oz gold per ton. Three adits exploring gold-bearing occurrences contain about: 550 tons averaging 0.03 oz gold per ton, 750 tons averaging 0.22 oz gold per ton, and 370 tons averaging $0.136 \mathrm{oz}$ gold per ton. This property ha moderate potential for gold resources.

Ten samples: three contalned 0.018 , 0.028 , and 0.03 oz gold per ton. contained gold ranging from 0.01 to $0.04 \mathrm{oz}$ per ton. One sample taken in the cut ylelded no significant values. Low potential for gold resources.

High potential for gold resources on basis of past production record and basis of past production record
reported activity during 1982.

\footnotetext{
loutside roadless area
${ }^{2}$ Partly in roadless area
} 


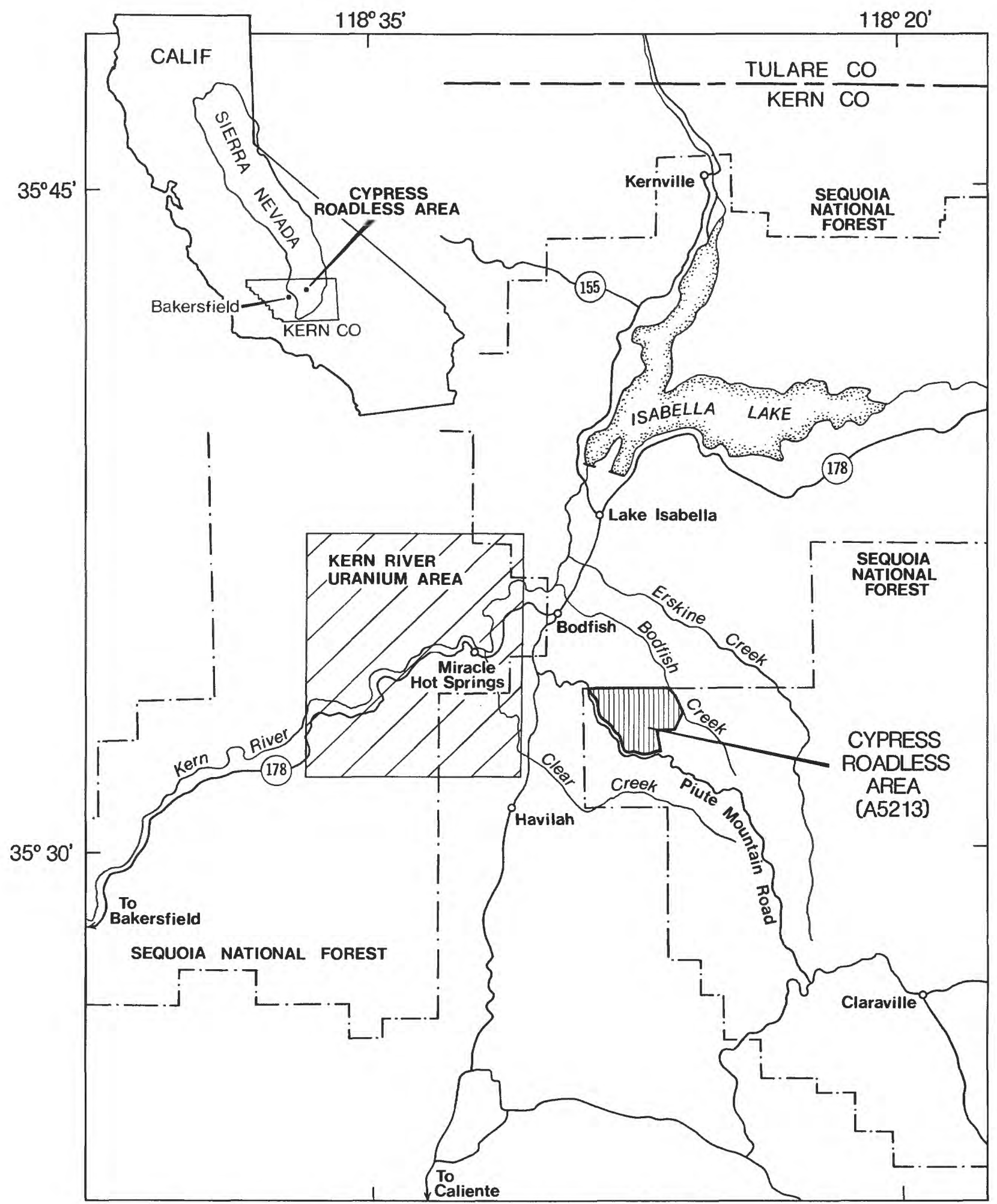

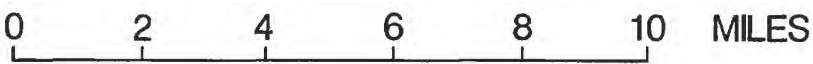

Figure 1 --Index map showing location of Cypress Roadless Area, Kern County, California. 


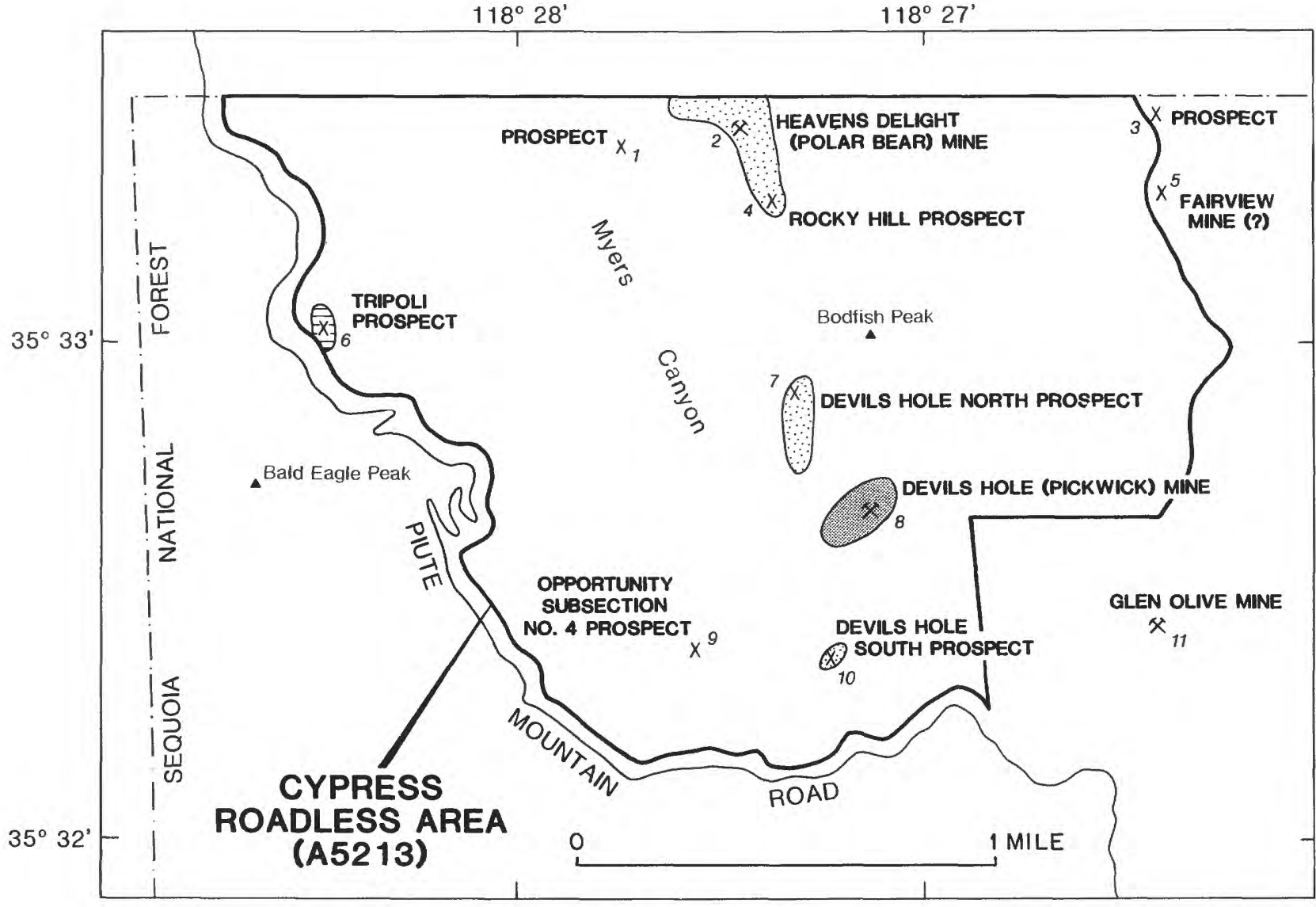

EXPLANATION

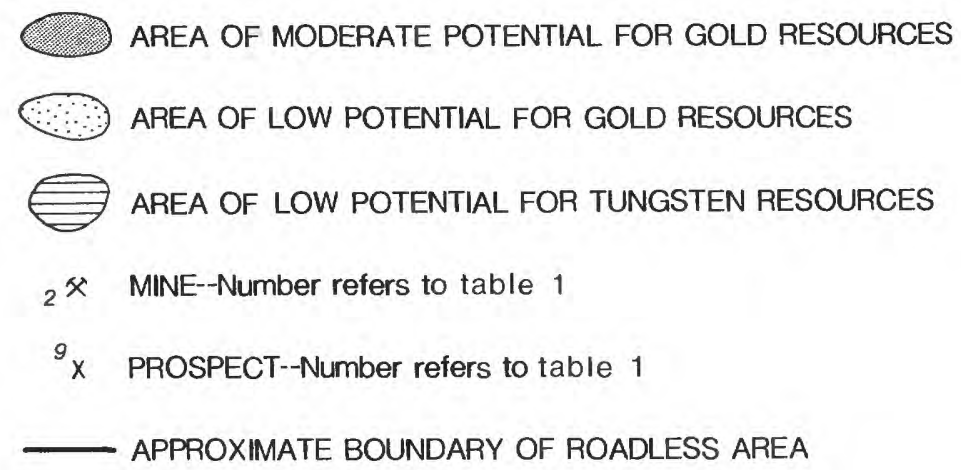

Figure 2.-Mineral resource potential map of Cypress Roadless Area. 
,

. 